\title{
Gender And Design: Gender Bias In Agrotechnology
}

\author{
Silvia Senjaya ${ }^{1}$, Yayuk Yuliati $^{2}$ \\ ${ }^{1}$ Program Magister Kajian Wanita, Universitas Brawijaya \\ Malang, 65145, Indonesia \\ ${ }^{2}$ Fakultas Pertanian, Universitas Brawijaya \\ Email korespondensi: silviathe78@student.ub.ac.id
}

Received 30 March 2021, Revised 21 April 2021, Accepted 21 May 2021

\begin{abstract}
The role of women as a farmer has existed in the history of human life for centuries. However, the Green Revolution made the role of women who were previously trusted to select seeds, weed, plant, fertilize, harvest and pound rice replaced by the role of technology. As with other designs and technologies, there has been a gender bias, so the researchers suspect that there is a gender bias in the design of agrotechnology which has an impact on the marginalization of female farmers. Through a literature review, researchers explored gender bias in the design of agrotechnology and its impact on female farmers. The design of agrotechnology is still genderbiased because it was designed without taking women's ergonomics. Women have different ergonomic characteristics from men, but that does not mean they cannot farm. Feminization of agriculture will be a profitable job opportunity for women if it is accompanied by the feminization intervention of agricultural machine and tool.

Keywords: Gender Bias, Design, Agrotechnology, Agriculture, Female Farmer
\end{abstract}

\section{INTRODUCTION}

In some countries, a large number of men leaving the countryside in search of better-paying jobs has sparked the feminization of agriculture. Feminization of agriculture is a phenomenon where women take control of the responsibility of agricultural activities due to the opening of employment opportunities for a wider range of male workers in the non-agricultural sector (eg. services and industry) which results are more profitable than in the agricultural sector. The role of women as farmers has existed in the history of human life for centuries. The division of labour that occurred during the hunting period at that time was that women were believed to cultivate the land to produce food, while men hunted. With this division of labour, women have a high social status in society because they are considered to be the breadwinner of the family. The position of women became strategic because they were respected by the family so that the social structure that developed at that time was matriarchal. Since the days of the kingdom in the Indonesian archipelago, women's involvement in agricultural activities has had a huge contribution, especially in the production subsystem where agricultural production activities carried out by women are strongly influenced by the type of agroecosystem and the socioeconomic status of the household. Many women take a central role during the agricultural production process to become a commodity that is ready to be marketed. However, during the New Order era, the idea of a green revolution emerged. This idea is an embodiment of the view of developmentalism which is the basis of the Soeharto government economy. The green revolution is a government effort to increase agricultural production using intensification and extensification. At this time Indonesia was able to become an Asian tiger because of its success in food self-sufficiency. But behind that, women farmers have become marginalized because the impact of the green revolution has changed the social structure of society. The green revolution made the role of women who were previously trusted to select seeds, weed, plant, fertilize, harvest and pound rice replaced by the role of technology. After the end of the green revolution, women farmers are currently foreigners to agricultural work, mainly because it is difficult to adapt to modernization in agriculture. The emergence of tractors, tractors (rice thresher machines), hullers (grinding machines), transplants (planting machines), and so on, has driven women out of work on agricultural land processing. Women farmers who previously had a role in agriculture have been replaced by machines. Moreover, the farmers who own the land prefer to use these tools more efficiently than the manual labour of women farmers. Efficiency and saving production capital are the reasons for agricultural landowners. The use of agricultural technology makes production capital smaller and more effective in completing processing even large areas of land. Guidance and protection of 
woman farmers need to be improved to accelerate the process of technology absorption by women farmers. There is a need for a protection strategy for female farmers by increasing the effectiveness of counselling and training, improving regulations, facilities, wages, job opportunities and safety so that they are gender-balanced. Besides that, what is no less important is the intervention in the design of agricultural machinery that is gender-friendly. According to researchers, this is one of the keys that is no less important in realizing gender justice in agriculture. Researchers suspect that there is a gender bias in the modernization of agricultural equipment designed without gender-sensitive considerations. Researchers will trace this conjecture through a literature review.

\section{RESEARCH METHOD}

The focus of this research is the design of agricultural tools and machines, and their relationship with female farmers. The research was conducted by searching the literature on agrotechnology; and its relationship with gender relations in agricultural culture in Indonesia.

\section{RESEARCH AND ANALYSIS Gender Bias}

Women and men are terms used by Indonesian society to distinguish two different genders. Sex is a biologically determined distinction between the two human sexes inherent in a particular gender (Mansour, 2013, p. 8). The term gender is always associated and even interpreted the same as the term gender. Though both have different definitions. Gender itself is a concept of differentiation between men and women based on a socio-cultural perspective, and not from the point of view of differences in nature. This distinction between the sexes affects the position, rights and obligations of women and men because of the values constructed by the community itself. The concept of gender is a trait inherent in women and men that is socially and culturally constructed by the community. For example, that woman is known for her gentle, beautiful motherly and emotional. Meanwhile, men are considered to be strong, manly, mighty, and rational. The characteristics of the trait itself are interchangeable traits, meaning that there are men who are gentle, motherly and emotional. Meanwhile, some women are strong, rational, and mighty. Changes in these characteristics and characteristics can occur from time to time, from one place to another, depending on the building desired by the social system of the community. For example, in the past, women were stronger than men, then in the next period, men were stronger than women. Or that change can occur from a certain class of society to another class of society. All things that can be exchanged between the characteristics of women and men from time to time, from one place to another, from one class to another, that is what is called the concept of gender.

In the course of the history of development in Indonesia, men and women have been declared as development resources whose participation is highly expected to bring about the welfare of Indonesian families. However, history also notes that development policies that have been declared to be neutral so far, in their implementation, gender imbalances often occur which in turn often lead to gender inequality. Gender inequality refers to a situation where one party is better than the other. Rothchild defines gender bias as "behaviour that shows favouritism toward one gender over another" (Rothchild, 2014). Gender bias is the tendency to prefer one gender over another. It is a form of unconscious bias, or implicit bias, which occurs when one individual unconsciously attributes certain attitudes and stereotypes to another person or group of people. For example, the wages of female agricultural labourers are much lower than that of men in the same type of work and working hours. This occurs because of the assumption that men are physically stronger, so they are considered entitled to higher wages. There is often no recognition of women's work, especially in the agricultural sector because agricultural work is considered men's work. In terms of agricultural technology information, men are often involved, women are rarely involved, so that in mastering agricultural technology, women are still far behind men. For example, there is a gap between men and women in Pringgabaya Subdistrict, East Lombok to access agricultural development program (Prasetyowati, Rini Endang; Tenaya, IM Narka; Astiti, NW Sri, 2014). The female farmer always has lagged due to limited access to development planning. Female farmer's access to Pringgabaya Subdistrict is very limited because the female farmer is only considered as the wife of the farmer. As a result, the ability and skills of a female farmer in agricultural technology are still low. Many female farmers are marginalized to become poor due to development programs such as agricultural intensification that only focus on male farmers.

\section{Gender Bias in Product Design}

In the world of product design, there is also gender inequality where women are excluded from their data and existence. Kat Ely researched 27 design and engineering consulting firms and found an unbalanced composition where only $24.4 \%$ of women were involved in the team. Of the 743 people who are members of the 27 firms, 555 are male, and 188 are female. Of these, only 34 women played a role in "physical product design". Some firms don't even have female designers at all (Ely, 2015). Design and engineering consultants create products for global markets, but the teams themselves rarely have the diversity that reflects global perspectives especially on gender. The small 
role of women in consideration and decision-making has led many designs to neglect to consider female consumers or female users. For example, experienced by Carol Reiley:

During my Ph.D. studies, I developed a voiceactivated human-robot interface for a surgical robotic system using Microsoft's speech recognition API. But, because the API had been built mainly by 20-30-year-old men, it did not recognize my voice. I had to lower my pitch in order for it to work. As a result, I was not able to present my own work. Although I had built the interface, a male graduate always had to lead the demonstration when we showed the system to distinguished visitors at the university, because the speech system recognized their voice but not mine. (Reiley, 2016)

Another example of gender bias is in the automotive field. Historically, the design and development of automotive products were largely defined by men. In the $1960 \mathrm{~s}$, vehicle accident test protocols called for testing with dolls that were tall, heavy and in stature to resemble male bodies. This means that seat belts are designed to make the car safe for men but not necessarily effective for women. Over the years, cars have been marketed neglecting the safety of women. As a result, female drivers have a 47 per cent greater risk of serious injury in a car accident. Fortunately, in 2011, crash testing began using female dolls in safety testing (Ely, 2015) (Reiley, 2016).

Craftsmanship is what has been culturally and historically considered a "men's job." Women are stereotypically perceived as less skilled than men. So when a product designer designs a carpentry tool, it is likely that the target demographic is male. It's no surprise that woodworking tools are often designed in ways that are more difficult for women to use. And in the end, the stereotype that women lacked skilled craftsmen became a reality. When human labour can be replaced by machines, it is often men who get more opportunities to be involved in machine-used work, than female workers. Similar stereotypes exist in agriculture. The stereotype that develops in society is that men are always stronger to work with agrotechnology than women. Inequality in the mastery of this tool is precise because the technology created is not gender friendly so that control of the technology is dominated by men.

\section{The Impact Of Modernization Of Agricultural Equipment For Women Farmers}

Engineering and utilization of agricultural tools and machinery, especially in the food crop and horticultural sub-sector, aims to fill labour shortages and lighten daily workloads so that efficiency and quality of production can be achieved. The use of four-wheeled tractors began to increase around the 1970s, as a result of the development of the intensification of lowland rice, which included the use of short-lived superior varieties, the recommendation for simultaneous planting and a short irrigation schedule so that the existing agricultural labour force was forced to spread throughout the region. The labour shortage at that time prompted some farmers to overcome the problem by using tractors. In post-harvest activities, there are two types of postharvest tools and machines, namely primary and secondary tools and machines. Primary postharvest tools and machines is a tool for handling crop yields related to the processing of crops involving: threshing, shelling, pressing, chopping, shovelling, etc. This agricultural tools and machines process raw materials so that they can be served into ready-to-process and readyto-store ingredients. Secondary postharvest agricultural tools and machines is a means of processing primary postharvest products into various kinds of ready-to-eat processed products. Secondary postharvest agricultural tools and machines are generally used by women. Paddy thresher tool to serve post-harvest activities (power and pedal thresher). The need for labour in rice farming is sometimes seasonal. The busy periods are the months of the growing, harvesting and threshing season. During that period, farmers often lacked labour, so the assistance of an unhulled paddy threshing machine was needed. Shedding is usually done by both men and women. This paddy thresher can also be operated by both male and female workers, although usually, the introduction of new technology will absorb more male workers than female workers. If, for example, a machine-powered paddy thresher is introduced, it will result in the men taking over the task of threshing unhulled rice previously done by women. Judging from the heavy workload of women it seems like this is profitable, but from the perspective of income, it means that women who previously did the work in exchange for money or an amount of rice, are disadvantaged by losing the source of income. Research on the impact of using thresher on reducing the income of female workers has not been done much. Taking this into account, to ease the burden on women, it would be better to introduce a thresher machine that is moved by foot or hand which makes the work easier but can still be done by women. The use of a dryer is still relatively small. For drying, most of the farmers still use the drying floor. Other agricultural tools such as rice milling unit, tapioca manufacture, rice flour, cassava chopper and tofu and tempe mill. There are still a few of these tools that are operated to facilitate women's work. Rice pounder. In some villages, women are reluctant to do the work of pounding rice, even though traditionally this work is done by them. Pounding rice is now done by a rice mill (huller). For the work, they had to pay and the owner of the milling machine also got the bran that was produced. 
Modernization of agricultural equipment increases the efficiency of agricultural work and increases crop yields. On the other hand, however, what needs to be considered is the marginalization of female farmers due to the modernization of an agricultural tool. Research by Harsoyo et al. (1999) showed that there was the marginalization of female workers in the salak Pondoh farming business due to the introduction of new high yielding varieties. The salak Pondoh farming business, which is much more intensive in management, hardly involves women. In this case, of the 13 types of work that are usually carried out by women farmers in local salak farming, there are only two types of work that can be done by female farmworkers. This means that there has been the marginalization of women. (Suhaeti \& Suharni, 2004)

\begin{tabular}{|l|l|}
\hline $\begin{array}{c}\text { Traditional agricultural } \\
\text { tools }\end{array}$ & Modern agricultural tools \\
\hline Ani-ani & Hand sprayer \\
Sabit & Tractor \\
Traditional Rice thresher & Combine harvester \\
Rope & Motorcycle and car \\
Natural pest control & Huller \\
Hoe & Rice thresher machine \\
Plough & \\
Traditional transportation & \\
Traditional rice pounder & \\
\hline Dominant by Women & Dominant by Men \\
\hline
\end{tabular}

Picture 1. Introduction of Agrotechnology in Indonesia (Sukesi, 2017)

In the tea picking activities at the Gambung tea plantation, female workers have a large participation in manual and scissor picking activities, while men dominate picking using picking machines (Sita \& Herawati, Gender Relation in Tea Plucking Workers: A Case Study of Gender Division of Labour and Gender Relation in Gambung Tea Plantation, West Java, 2017). Mechanical picking has not yet fully provided opportunities for female workers to be involved because picking machines are not ergonomic for women or have not had a gender perspective. They only use their hands and plucked scissors because the machine tools are heavy enough to be operated by women and the machines are not yet ergonomic for women's bodies. One of the female workers said that being a tea picking machine operator was very risky. Carrying a picking machine is not an easy and light job. The picking machine has a very strong vibration. After work, the body often feels achy. Feet and shoulders withstand the weight of the picking machine and the risk of falling sprain if the picking passageway is slippery. The noise from the engine exhaust makes the ears hurt. So, female workers are not involved in picking by picking machines. This opens opportunities for gender inequality in the socio-economic context, namely the possibility of women losing the opportunity to participate in the world of work if they cannot adapt to mechanization. However, in subsequent studies: "Gender dan Mekanisasi: Pengalaman Pekerja Perempuan Berpartisipasi dalam Kelompok Petik Mesin di Perkebunan Teh Gambung, Jawa Barat (Gender and Mechanization: Experience of Female Workers Participating in machine-picking tea at Gambung Tea Plantation, West Java)", Sita found that there were women who used picking machines. It turns out that there was a female worker's interest in trying and participating in using picking machines. This shows women's efforts to maintain their role and existence in the tea production chain and the goal of improving their household socio-economic conditions. Unfortunately, although using picking machines generates large wages, equal to male workers, there are complaints that the large costs for medical treatment are also due to the risk of the work. Although technology is not yet gendered friendly, many other obstacles that limit female workers from adopting technology. These constraints lack access and control of resources, barriers to cultural norms, values and assumptions that have been embedded in a society where women are synonymous with jobs associated with human traits: smooth and painstaking nature. Thus, the framework for implementing mechanization of tea picking in tea plantations in the future, which inevitably will occur, needs to require the concept of sustainable gender participation so that productive benefits can be felt by men and women. This is also a form of maintaining and enhancing the position and participation of women in the tea value chain in Indonesia in a sustainable manner. Technology will succeed in reducing the workload of women if it physically follows the needs and physical conditions of women, and this is gender-friendly technology. (Sita, Gender dan Mekanisasi: Pengalaman Pekerja Perempuan Berpartisipasi dalam Kelompok Petik Mesin di Perkebunan Teh Gambung, Jawa Barat , 2019)

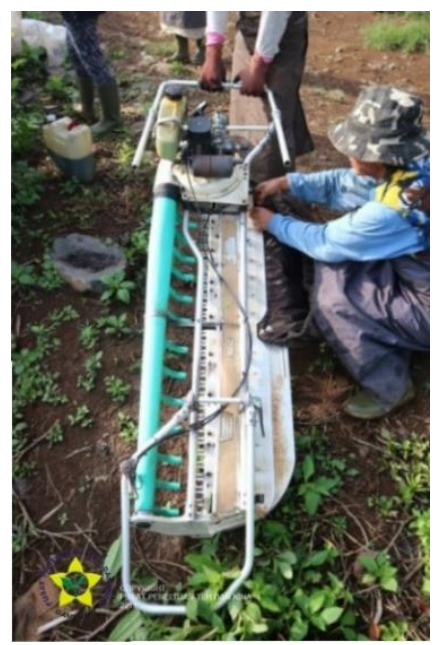

Picture 2. "Sanyang" Tea Picking Machines used in Gambung Tea Plantation (Yulianti \& Haq, 2019) 


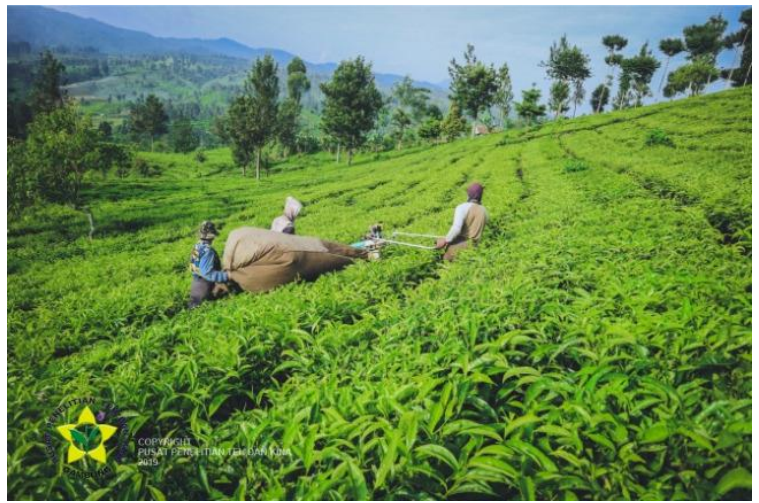

Picture 3. Tea picking activities using machines in Gambung Tea Plantation (Yulianti \& Haq, 2019)

\section{Potential for Gender Friendly Agrotechnology Development}

Women have different ergonomic characteristics from men. There is a need to design gender-friendly machinery so that women can operate this tool comfortably. This will reduce musculoskeletal disorders, reduce the risk of work injury and accidents, and increase the productivity of female farmers. On average, women are shorter than men. Women also have narrower shoulders, wider hips and proportionately shorter legs and arms and arms than men. Women are more likely to experience shoulder and neck muscle disorders than men because the upper body muscles are weaker than men. Physical impairment, especially the risk of musculoskeletal disorders due to uncomfortable work postures is associated with working with agricultural implements can be minimized or prevented by appropriate ergonomic interventions in which production standards and work equipment are adjusted to the size and capacity of women's bodies. (Singh \& Arora, 2010)

Several agrotechnologies are now widely available but are still more popular among the male workforce. This is because these machines are designed to be operated by male power. Women have different ergonomic characteristics from men. designing technology without considering the differences in ergonomics of men and women can pose ergonomic risks and endanger work safety. This is gender inequity. So, research and development with a gender perspective are needed to eliminate gender bias in agrotechnology because the application of technology will benefit all mankind if it can be used productively by both male and female human resources.

\section{CONCLUSION}

Feminization of agriculture will be a profitable job opportunity for women if it is accompanied by the feminization intervention of agrotechnology. Technology is generally created for positive purposes to help increase social and economic development. But in fact, the design of agrotechnology is still gendered biased because it was designed without taking women's ergonomics. The myth that technology is the same as machines and machines only provided for men, must be eliminated. So that it becomes a consideration for design gender-friendly agrotechnology. This is a challenge for product designers to design genderfriendly agrotechnology because the choice of a form of technology is thus a very decisive decision, and will have an impact on the entire network of social and economic structures of society.

\section{DAFTAR PUSTAKA}

Ely, K. (2015, Sep 8). The World is Designed for Men. Retrieved from medium.com: https://medium.com/hh-design/the-world-isdesigned-for-men-d06640654491

Ely, K. (2015, Sep 8). The World is Designed for Men. Retrieved from medium.com: https://medium.com/hh-design/the-world-isdesigned-for-men-d06640654491

Mansour, F. (2013). Analisis Gender dan Transformasi Sosial. Yogyakarta: Pustaka Pelajar.

Prasetyowati, Rini Endang; Tenaya, IM Narka; Astiti, NW Sri. (2014). Peran Wanita Tani dalam Penerapan Teknologi Pengelolaan Tanaman Terpadu (PTT) pada Usahatani Jagung di Kecamatan Pringgabaya Kabupaten Lombok Timur. Jurnal Manajemen Agribisnis, 76-83.

Reiley, C. (2016, Nov 17). When bias in product design means life or death. Retrieved from techcrunch.com:

https://techcrunch.com/2016/11/16/when-bias-inproduct-design-means-life-or-death/

Rothchild, J. (2014, November 07). Gender Bias. The Blackwell Encyclopedia of Sociology.

Singh, S., \& Arora, R. (2010). Ergonomic Intervention for Preventing Musculoskeletal Disorders. Journal of Agricultural Sciences, 61-71.

Sita, K. (2019). Gender dan Mekanisasi: Pengalaman Pekerja Perempuan Berpartisipasi dalam Kelompok Petik Mesin di Perkebunan Teh Gambung, Jawa Barat . Umbara: Indonesian Journal of Anthropology, 76-88.

Sita, K., \& Herawati, E. (2017). Gender Relation in Tea Plucking Workers: A Case Study of Gender Division of Labour and Gender Relation in Gambung Tea Plantation, West Java. Sodality: Jurnal Sosiologi Pedesaan, 1-8.

Suhaeti, R. N., \& Suharni, S. (2004). Inkorporasi Perspektif Gender dalam Pengembangan Rekayasa Alat danMesin Pertanian. SOCA: Jurnal Sosial Ekonomi Pertanian.

Sukesi, K. (2017, Juli 26-28). Peran Gender dalam Adopsi Teknologi Pertanian di Pedesaan. Kegiatan FGD Pengarusutamaan Gender -KEMENTAN. Manado.

Yulianti, D., \& Haq, S. M. (2019, July 15). Pemetikan Teh dengan Mesin Petik. Retrieved from Pusat Penelitian Teh dan Kina: https://www.gamboeng.com/post/read/2019/179/ Pemetikan-Teh-dengan-Mesin-Petik 